\title{
UJI STABILITAS FISIK DAN HEDONIK SIRUP HERBAL KUNYIT ASAM STABILITY AND HEDONIC TEST OF TUMERIC TAMARIND SYRUP
}

\author{
Indri Kusuma Dewi, Youstiana Dwi Rusita \\ Kementerian Kesehatan Politeknik Kesehatan Surakarta Jurusan Jamu
}

\begin{abstract}
Physical Stability, Hedonic, Syrup, Tumeric Tamarind. Tumeric have a benefit as antiinflammation so can be improved in the syrup formula. This research aimed to describe the result physical stability and hedonic test of the tumeric tamarind sirup with differences temperature storing for phormula I was saving in $5^{\circ} \mathrm{C}$ and phormula II was saving in $35^{\circ} \mathrm{C}$ for 24 hours as many 14 cyclic. It was experimental research. This research was done by testing physical stability of the tumeric tamarind sirup include to organoleptic, $p H$, homogenity and pour time test and also hedonic test. The result research: organoleptic test were no change for two weeks with brownish yellow colour, smell test is tumeric tamarind, flavor test is sweet and tamarind and texture is solid. $\mathrm{pH}$ test is stable at 4, homogenity test is stable homogen and pour time test is phormula I was storing in $5^{\circ} \mathrm{C}$ is 8,14 second and 7,84 second, phormula II was storing in $35^{\circ} \mathrm{C}$ is 5,04 second and 4,14 second for 24 hour as many 14 cyclic. Hedonic test was showed result for first week at temperature $5^{\circ} \mathrm{C}$ is $40 \%$ of respondents are very like, $40 \%$ of respondents are like and $20 \%$ of respondents are dislike, at temperature $35^{\circ} \mathrm{C}$ is $40 \%$ of respondents are very like and $60 \%$ of respondents are like. While for second week at temperature $5^{\circ} \mathrm{C}$ is $60 \%$ of respondents are very like and $40 \%$ of respondents are like, at temperature $35^{\circ} \mathrm{C}$ is $80 \%$ of respondents are very like and $20 \%$ of respondents are like.
\end{abstract}

\section{Keyword : Physical Stability, Hedonic, Syrup, Tumeric Tamarind}

\begin{abstract}
Abstrak: Stabilitas Fisik, Hedonik, Sirup,Kunyit Asam. Kunyit mempunyai manfaat sebagai anti inflamasi sehingga pemanfaatannya dapat dikembangkan dalam bentuk sirup. Tujuan penelitian ini untuk mengetahui gambaran hasil stabilitas fisik dan hedonik sirup herbal dengan perbedaan suhu penyimpanan yaitu formula I disimpan pada suhu $5^{\circ} \mathrm{C}$ dan formula II disimpan pada suhu $35^{\circ} \mathrm{C}$ selama 24 jam sebanyak 14 siklus. Jenis penelitian adalah eksperimental. Penelitian dilakukan dengan menguji stabilitas fisik sirup herbal kunyit asam yang meliputi organoleptik, $\mathrm{pH}$, homogenitas dan waktu tuang serta uji hedonik. Hasil pengamatan organoleptis tidak mengalami perubahan selama 2 minggu yaitu warna kuning kecoklatan pekat, bau khas kunyit asam, rasa asam manis dan bentuk cair. Hasil uji $\mathrm{pH}$ tetap stabil yaitu 4,uji homogenitas adalah tetap homogen dan hasil waktu tuang formula I disimpan pada suhu $5^{\circ} \mathrm{C}$ yaitu 8,14 detik dan 7,84 detik dan formula II disimpan pada suhu $35^{\circ} \mathrm{C}$ yaitu 5,04 detik dan 4,14 detik selama 24 jam sebanyak 14 siklus. Untuk uji hedonik menunjukkan hasil respon pada minggu I suhu $5^{\circ} \mathrm{C}$ yang sangat suka $40 \%$, suka $40 \%$ dan tidak suka $20 \%$, pada suhu $35^{\circ} \mathrm{C}$ memberikan nilai respon yang sangat suka $40 \%$, suka $60 \%$. Sedangkan pada minggu II suhu $5^{\circ} \mathrm{C}$ yang sangat suka $60 \%$, suka $40 \%$, pada suhu $35^{\circ} \mathrm{C}$ memberikan nilai respon yang sangat suka $80 \%$, suka $20 \%$.
\end{abstract}

Kata Kunci : Stabilitas Fisik, Hedonik, Sirup, Kunyit Asam 


\section{PENDAHULUAN}

Salah satu pemanfaatan bahan alam adalah dalam bentuk sediaan minuman herbal atau jamu yang diharapkan bermanfaat bagi kesehatan sebagai pangan fungsional. Pangan fungsional adalah pangan yang secara alami maupun telah melalui proses mengandung satu atau lebih senyawa yang berdasarkan kajian-kajian ilmiah dianggap mempunyai fungsi-fungsi fisiologis tertentu yang bermanfaat bagi kesehatan. Pangan fungsional dikonsumsi sebagaimana layaknya makanan atau minuman, mempunyai karakteristik sensori berupa penampakan, warna, tekstur dan cita rasa yang dapat diterima oleh konsumen, serta tidak memberikan kontraindikasi dan efek samping terhadap metabolisme zat gizi lainnya jika digunakan dalam jumlah yang dianjurkan (BPOM, 2001)

Contoh minuman herbal atau jamu sebagai pangan fungsional adalah sirup. Pada penelitian ini bahan alam yang dikembangkan dalam bentuk sediaan sirup adalah kunyit asam. Menurut Rustam dkk (2007), seluruh kelompok dosis ekstrak etanol kunyit mempunyai manfaat sebagai anti inflamasi. Hal ini dikarenakan adanya kurkumin yang dapat menghambat prostaglandin dan menekan aktivitas enzim siklooksigenase (Sudjarwo, 2004). Rimpang kunyit dapat dibuat dalam bentuk sirup karena praktis penggunaannya tetapi mempunyai rasa pahit sehingga perlu ditambahkan pemanis (Kusumawati dkk., 2015).

Setelah mendapatkan formulasi kunyit asam dalam bentuk sirup kemudian dilakukan stabilitas fisik untuk mengetahui umur simpan sirup secara penampilan fisik yaitu meliputi pengamatan organoleptis, $\mathrm{pH}$, viskositas serta dilakukan uji hedonik untuk mengetahui kesukaan responden terhadap sirup herbal kunyit asam.

Penelitian untuk uji stabilitas fisik dan hedonik sirup herbal kunyit asam belum pernah dilakukan sebelumnya. Tujuan penelitian ini untuk mengetahui hasil stabilitas fisik dan hedonik sirup herbal dengan perbedaan suhu penyimpanan yaitu formula I disimpan pada suhu $5^{\circ} \mathrm{C}$ dan formula II disimpan pada suhu $35^{\circ} \mathrm{C}$ selama 24 jam sebanyak 14 siklus.

\section{METODE PENELITIAN \\ Bahan}

Kunyit, asam jawa, kayu manis, garam, gula pasir, gula aren dan aquadest.

\section{Alat}

Gelas ukur, penangas air, pengaduk, panci stainless steel, blender, saringan, $\mathrm{pH}$ meter, termometer, viskometer Ostwald, neraca analitik.

\section{Prosedur eksperimen}

A. Formulasi sirup kunyit asam

$\mathrm{R} /$

$\begin{array}{ll}\text { Kunyit } & 50 \text { gram } \\ \text { Asam } & 50 \text { gram } \\ \text { CMC Na } & 0,5 \% \\ \text { Kayu Manis } & 10 \text { gram } \\ \text { Gula Pasir } & 400 \text { gram } \\ \text { Gula aren } & 50 \text { gram } \\ \text { Garam } & \text { q.s } \\ \text { Air }(\mathrm{ad} .) & 500 \mathrm{ml}\end{array}$

Pembuatan:

Perasan kunyit dimasukkan ke panci stainless, lalu panaskan di atas kompor. Kemudian menambahkan asam, gula pasir, gula aren dan diaduk sampai gulanya melarut.Tambahkan garam secukupnya, kurang lebih setengah sendok teh. Setelah gula sudah melarut dan sirup 
sudah mendidih, matikan api, diamkan sampai sirup menjadi hangat.

b. Uji stabilitas sirup kunyit asam Sirup kunyit asam sebelum dievaluasi stabilitas mutunya diberikan kondisi penyimpanan dipercepat yaitu penyimpanan pada suhu $5^{\circ} \mathrm{C}$ dan $35^{\circ} \mathrm{C}$ masingmasing selama 24 jam sebanyak 14 siklus, kemudian dilakukan pengujian-pengujian berikut :

\section{a. Pemeriksaan organoleptik}

Pemeriksaan meliputi perubahan warna dan bau. Sirup yang telah dibuat diperiksa bau dan warnanya sebelum dan sesudah dilakukan penyimpanan yang dipercepat, tiap satu siklus

b.Pemeriksaan homogenitas

pemeriksaan meliputi ada atau tidaknya gumpalan atau endapan pada larutan.

\section{c. Pengukuran pH}

Pengukuran $\mathrm{pH}$ dilakukan dengan menggunakan $\mathrm{pH}$-meter terhadap $\mathrm{pH}$ sirup sebelum dan sesudah kondisi penyimpanan yang dipercepat.

\section{d. Pengukuran viskositas}

Pengukuran viskositas dilakukan terhadap sirup yang telah dibuat sebelum dan sesudah kondisi penyimpanan dipercepat. Pengukuran viskositas dilakukan dengan menggunakan viskometer Ostwald

c. Uji hedonik

Sirup dicobakan kepada 25 orang responden dan kemudian responden diminta untuk mengisi kuisioner yang isinya meliputi rasa, aroma dan penampilan.

\section{HASIL PENELITIAN}

\section{A. Berdasarkan hasil pengamatan} selama 24 jam sebanyak 14 siklus

\begin{tabular}{|c|c|c|c|c|}
\hline $\begin{array}{c}\text { Penguji } \\
\text { an }\end{array}$ & $\begin{array}{c}\begin{array}{c}\text { Hasil } \\
\text { Pengamatan }\end{array} \\
\text { Minggu I } \\
\text { Suhu } 5^{\circ} \mathrm{C}\end{array}$ & $\begin{array}{l}\text { Minggu II } \\
\text { Suhu } 35^{\circ} \mathrm{C}\end{array}$ & $\begin{array}{l}\text { Suhu } \\
5^{\circ} \mathrm{C}\end{array}$ & $\begin{array}{l}\text { Suhu } \\
35^{\circ} \mathrm{C}\end{array}$ \\
\hline $\begin{array}{l}\text { Organo } \\
\text { leptis }\end{array}$ & Cair & Cair & Cair & Cair \\
\hline Bentuk & $\begin{array}{l}\text { Khas Kunyit, } \\
\text { Asam Manis }\end{array}$ & $\begin{array}{l}\text { Khas Kunyit, } \\
\text { Asam Manis }\end{array}$ & $\begin{array}{l}\text { Khas } \\
\text { Kunyit } \\
\text {, Asam }\end{array}$ & $\begin{array}{l}\text { Khas } \\
\text { Kunyit } \\
\text {, Asam }\end{array}$ \\
\hline Bau & $\begin{array}{l}\text { Kuning } \\
\text { Kecoklatan }\end{array}$ & $\begin{array}{l}\text { Kuning } \\
\text { Kecoklatan }\end{array}$ & Manis & Manis \\
\hline Warna & $\begin{array}{l}\text { Pekat } \\
\text { Manis dan } \\
\text { Asam }\end{array}$ & $\begin{array}{l}\text { Pekat } \\
\text { Manis dan } \\
\text { Asam }\end{array}$ & $\begin{array}{l}\text { Kunin } \\
\text { g } \\
\text { Kecokl } \\
\text { atan } \\
\text { Pekat }\end{array}$ & $\begin{array}{l}\text { Kunin } \\
\text { g } \\
\text { Kecokl } \\
\text { atan } \\
\text { Pekat }\end{array}$ \\
\hline & & & $\begin{array}{l}\text { Manis } \\
\text { dan } \\
\text { Asam }\end{array}$ & $\begin{array}{l}\text { Manis } \\
\text { dan } \\
\text { Asam }\end{array}$ \\
\hline $\begin{array}{l}\text { Rasa } \\
\text { Homog } \\
\text { enitas } \\
\text { pH }\end{array}$ & $\begin{array}{l}\text { Homogen } \\
4\end{array}$ & $\begin{array}{l}\text { Homogen } \\
4\end{array}$ & $\begin{array}{l}\text { Homo } \\
\text { gen } \\
4\end{array}$ & $\begin{array}{l}\text { Homo } \\
\text { gen } \\
4\end{array}$ \\
\hline $\begin{array}{l}\text { Waktu } \\
\text { Tuang }\end{array}$ & 8.14 Detik & 5,04 Detik & $\begin{array}{l}7.84 \\
\text { Detik }\end{array}$ & $\begin{array}{l}4,12 \\
\text { Detik }\end{array}$ \\
\hline
\end{tabular}

\section{PEMBAHASAN}

\section{Stabilitas Sirup Kunyit Asam}

Pengujian stabilitas Sirup Kunyit Asam berdasarkan percobaan yang dilakukan oleh Pakki et al, 2011 yaitu dengan penyimpanan sirup pada suhu $5^{\circ} \mathrm{C}$ dan $35^{\circ} \mathrm{C}$ masing-masing selama 12 jam sebanyak 10 siklus, dengan pengujian dilakukan setiap hari dengan parameter fisik meliputi organoleptik, $\mathrm{pH}$, homogenitas, waktu tuang.

a. Uji Organoleptik

Uji organoleptik sediaan sirup kunyit asam meliputi warna, rasa, bau, dan bentuk. Hasil uji organoleptik diperoleh dari sediaan sirup adalah kuning kecoklatan pekat dan tidak 
terjadi perubahan saat penyimpanan selama 2 minggu baik pada suhu dingin maupun suhu ruangan. Warna sirup tersebut sesuai dengan warna ekstrak cair yaitu kuning pekat dan berwarna kecoklatan ketika di campur dengan asam jawa. Warna asli daging asam adalah kuning kecoklat-coklatan, sedangkan warna pada kuning pada kunyit yaitu adanya kurkumin. Kurkumin berbentuk serbuk kristal dengan warna kuning jingga, selain itu juga memberikan sumbangan terhadap karakter kepedasan yang lembut pada rempah (Koswara, S, 2009). Rimpang kunyit kering mengandung kurkuminoid sekitar $10 \%$, kurkumin $1-5 \%$, dan sisanya terdiri dari demetoksikurkumin, serta bisdemetoksikurkumin. Selain itu rimpang kunyit juga mengandung minyak atsiri sebanyak $1-3 \%$, lemak, protein, karbohidrat, pati, dan sisanya terdiri dari vitamin $\mathrm{C}$, garam-garam mineral seperti zat besi, fosfor, dan kalsium. Bau dan rasa berasal dari beberapa zat yang terdapat didalam minyak tersebut. Zat-zat tersebut meliputi keton sesquiterpen, termeron, zingeberen, borneol, dan sineol (Nugroho, 1998). Sedangkan daging buah asam jawa mengandung $8-14 \%$ asam tartarat, $30-40 \%$ gula, serta sejumlah kecil asam sitrat dan kalium bitaetrat sehingga berasa sangat masam (Rukmana, 2005). Tidak adanya perubahan warna dan bau pada sediaan menunjukkan bahwa tidak ada interaksi pada komponen didalamnya yaitu antara rimpang kunyit dan asam jawa. Karakteristik sirup kunyit asam yang kental karena adanya CMC Na dan sukrosa. Tekstur sirup kunyit asam agak kental karena pengaruh penambahan $\mathrm{CMC} \quad \mathrm{Na}$ dan konsentrasi dari sukrosa yang digunakan.

b. Uji pH

Pada pengamatan stabilitas

berdasarkan parameter waktu

penyimpanan pada suhu tertentu terhadap nilai $\mathrm{pH}$ sediaan terlihat bahwa semua sediaan sirup mempunyai nilai $\mathrm{pH}$ yang stabil yaitu 4. Pengujian $\mathrm{pH}$ merupakan salah satu parameter yang penting karena nilai $\mathrm{pH}$ yang stabil dari larutan menunjukkan bahwa proses distribusi dari bahan dasar dalam sediaan merata. Nilai $\mathrm{pH}$ yang dianjurkan untuk sirup adalah berkisar antara 4 -7 (Anonim, 1995). Adanya asam sitrat yang terkandung pada daging buah asam jawa dalam penelitian ini berfungsi sebagai pendapar yang bersifat menstabilkan $\mathrm{pH}$ yaitu \pm 4 sehingga warna sirup stabil dalam penyimpanan suhu tinggi. Pada pengujian $\mathrm{pH}$ semua sirup yang dihasilkan masih memenuhi parameter nilai $\mathrm{pH}$ yang dipersyaratkan.

c. Uji homogenitas

Pada uji homogenitas semua sirup yang diuji tidak memiliki gumpalan dan endapan dalam larutan, hal ini karena tidak terdapat perbedaan sifat antara bahan dan zat aktif yang digunakan (Lachman, 1994).

d. Uji waktu tuang

Uji ini dilakukan untuk mengetahui kemudahan tuang sediaan saat nanti akan dikonsumsi. Uji ini berhubungan erat dengan kekentalan suatu sediaan. Jika kekentalan yang rendah menjadikan cairan akan semakin mudah dituang dan sebaliknya, jika viskositas atau kekentalan semakin besar, maka 
cairan akan semakin sukar dituang (Ansel, 1989). Viskositas cairan biasanya turun dengan meningkatnya suhu, dapat dianalogikan dengan sirup gula panas mengalir lebih cepat dari pada sirup gula dingin.

\section{B. Berdasarkan data hasil uji hedonik} pada sirup herbal kunyit

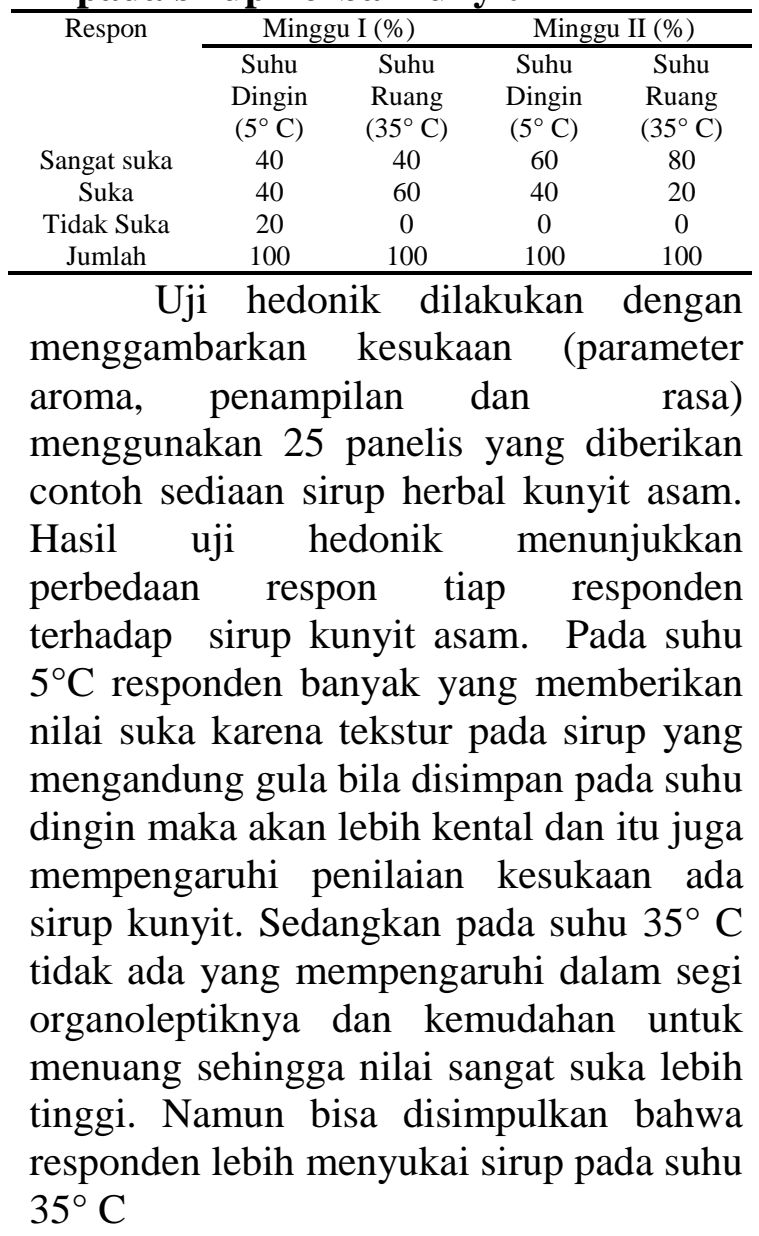

\section{KESIMPULAN DAN SARAN}

Stabilitas fisik dan hedonik sirup herbal kunyit asam dengan perbedaan suhu penyimpanan yaitu formula I disimpan pada suhu $5^{\circ} \mathrm{C}$ dan formula II disimpan pada suhu $35^{\circ} \mathrm{C}$ selama 24 jam sebanyak 14 siklus. a. Bentuk, warna, bau dan rasa formula I disimpan pada suhu $5^{\circ} \mathrm{C}$ dan formula II disimpan pada suhu $35^{\circ} \mathrm{C}$ selama 24 jam sebanyak 14 siklus tidak mengalami perubahan yaitu warna kuning kecoklatan pekat, bau khas kunyit dan asam, rasa asam manis dengan bentuk cair

b. Uji $\mathrm{pH}$ formula I disimpan pada suhu $5^{\circ} \mathrm{C}$ dan formula II disimpan pada suhu $35^{\circ} \mathrm{C}$ selama 24 jam sebanyak 14 siklus tidak ada perubahan yaitu nilai 4

c. Uji homgenitas formula I disimpan pada suhu $5^{\circ} \mathrm{C}$ dan formula II disimpan pada suhu $35^{\circ} \mathrm{C}$ selama 24 jam sebanyak 14 siklus tidak ada endapan dan gumpalan semua homogen

d. Uji waktu tuang formula I disimpan pada suhu $5^{0} \mathrm{C}$ yaitu 8,14 detik dan 7,84 detik dan formula II disimpan pada suhu $35^{\circ} \mathrm{C}$ yaitu 5,04 detik dan 4,14 detik selama 24 jam sebanyak 14 siklus

e. Untuk uji hedonik menunjukkan hasil respon pada minggu I suhu $5^{\circ} \mathrm{C}$ yang sangat suka $40 \%$, suka $40 \%$ dan tidak suka $20 \%$, pada suhu $35^{\circ} \mathrm{C}$ memberikan nilai respon yang sangat suka $40 \%$, suka $60 \%$. Sedangkan pada minggu II suhu $5^{\circ} \mathrm{C}$ yang sangat suka $60 \%$, suka $40 \%$, pada suhu $35^{\circ} \mathrm{C}$ memberikan nilai respon yang sangat suka $80 \%$ dan suka $20 \%$.

\section{DAFTAR RUJUKAN}

Anonim. 1995. Farmakope Indonesia Edisi IV. Departemen Kesehatan Republik Indonesia : Jakarta. 
Ansel H.C. 1989. Pengantar Bentuk Sediaan Farmasi. Jakarta : UI Press, pp : $605-19$.

BPOM.2001. Kajian proses standarisasi produk pangan fungsional di badan Pengawas Obat dan Makanan. Lokakarya Kajian Penyusunan Standar Pangan Fungsional. Badan Pengawasan Obat dan Makanan, Jakarta.

Koswara, S, 2009, Pewarna alami: Produksi dan Penggunaannya. eBookPangan.com.

Kusumawati C.,Mufrod dan Mutmainah. 2015. Karakteristik Fisik dan Penerimaan Rasa Sediaan Chewable Lozenges Ekstrak Rimpang Kunyit (Curcuma domestica Val.) dengan Kombinasi Pemanis High Fructose Syrup dan Sukrosa. Majalah Farmasetik Vol 11 No 1 tahun 2015.

Lachman, L., A. H. Lieberman., J.L.Kanig. 1994. Teori dan Praktek Farmasi Industri. Terjemahan Siti Suyatmi. UIPres,: Jakarta.

Nugroho NA. 1998. Manfaat dan Prospek Pengembangan Kunyit. Ed ke-1. Ungaran: PT.Trubus Agriwidya

Pakki.E, Usmar dan Rahmawati S. 2011. Formulasi dan Uji Stabilitas Sediaan Minuman Herbal Imunomodulator Berbasis Rumput Laut. Majalah Farmasi dan Farmakologi. Vol 15 No 1 Maret 2011.

Rustam. E, Atmasari. I dan Yanwirasti. 2007. Efek Antiinflamasi Ekstrak Etanol Kunyit (Curcuma domestica Val.) Pada Tikus Putih Jantan Galur Wistar. Jurnal Sains dan Teknologi Farmasi Vol 12 (2):
Fakultas Kedokteran Universitas Andalas.

Rukmana,R.,2005. Budidaya Asam Jawa. Kanisius. Yogyakarta

Sudjarwo,S.A. 2004.The Signal

Transduction of Curcumin as Anti Inflammatory Agent in Cultured Fibroblasts. Jurnal Kedokteran YARSI vol.12 